\title{
PREDIKTOR YANG MEMPENGARUHI PELAKU DAN KORBAN PERUNDUNGAN MAYA
}

\author{
Faiqoh \\ Universitas Islam Negeri Syarif Hidayatullah \\ E-mail: okefaiqoh@gmail.com
}

\begin{abstract}
This study was aimed to predict cyber-bullying by self esteem, academic performance, and lonliness. The participants of the study were 313 junior high school students that selected by nonprobability sampling technique. This study used eight instruments that were validated by confirmatory factor analysis and was analyzed by multiple regression. The results of the study were significant prediction of peer-related loneliness, affective performance, and gender to cyber-bulliers and significant preditctions to cyber-bullying victims by peer-related loneliness, in affective performance.
\end{abstract}

Keywords: cyber-bullying, self-esteem, loneliness, academic achievement

\begin{abstract}
Abstrak
Penelitian ini dilakukan untuk melihat prediktor dari pelaku dan korban perundungan maya. Data yang dianalisis dalam penelitian ini berjumlah 313 orang, terdiri dari siswa-siswi SMP kelas 7 dan 8 di Tangerang Selatan. 166 siswa berjenis kelamin perempuan dan 147 siswa berjenis kelamin laki-laki dengan menggunakan teknik non-probability sampling. Penelitian ini menggunakan kuesioner dengan model skala Likert. Analisis faktor konfirmatori digunakan untuk mengukur validitas skala, dan pengujian hipotesis menggunakan analisis regresi ganda. Hasil penelitian ini menunjukkan bahwa ada pengaruh yang signifikan kesepian pada teman, prestasi akademik ranah afektif, dan jenis kelamin terhadap pelaku perundungan maya, sedangkan bagi korban perundungan maya dipengaruhi oleh kesepian pada teman dan prestasi akademik ranah afektif.
\end{abstract}

Kata kunci: perundungan maya, harga diri, kesepian, prestasi akademik.

\section{PENDAHULUAN}

Perundungan atau bullying didefinisikan sebagai perilaku agresif berulang di mana ada ketidakseimbangan kekuatan antar pihak. Secara tradisional tindakan ini berupa ancaman fisik (misalnya, memukul, mendorong), pelecehan verbal (misal: mengejek, memanggil nama julukan) baik secara terang-terangan maupun halus, pengucilan sosial dan menyebarkan rumor. Saat ini, komunikasi elektronik menjadi media anak-anak dan remaja untuk melakukan perundungan. Perundungan melalui media elektronik disebut perundungan maya. 
Perundungan maya merupakan ancaman atau melakukan fitnah yang bersifat disengaja dan diulang oleh seseorang atau kelompok yang dimaksudkan untuk menyakiti orang lain dengan menggunakan teknologi informasi dan komunikasi seperti e-mail, ponsel dan pesan teks pager atau pesan instan (Besley dalam Shariff, 2009; Tokunaga, 2010). Sedangkan menurut Nancy Willard (2007), perundungan maya adalah bertindak kejam terhadap orang lain dengan mengirimkan atau mencantumkan materi yang menyakiti atau terlibat dalam bentukbentuk lain agresi sosial menggunakan internet atau teknologi lainnya.

Dampak negatif dari perundungan maya telah banyak ditemukan oleh para peneliti. Olweus (2012), Goebert, Else, Matsu, Chung-Do, dan Chang (2011), Price dan Dalgleish (2010), menemukan dampak perundungan maya yang kurang lebih sama seriusnya dengan dampak yang ditimbulkan oleh intimidasi tradisional antara lain: emosi distress, depresi, harga diri yang rendah, kecemasan, percobaan bunuh diri, dan masalah-masalah psikosomatik seperti: sakit kepala, sulit tidur. Dampak negatif lainnya yang ditemukan adalah prestasi akademik (Beran \& Li, 2007; Patchin \& Hinduja, 2006; Ma, 2001). Ironisnya, 20-40\% remaja mengalami perundungan maya minimal satu kali dalam hidup mereka (Tokunaga, 2010). Juga, Patchin dan Hinduja (2006) menemukan bahwa 47\% siswa yang berusia 9-18 tahun telah menyaksikan perundungan maya.

Peningkatan perundungan maya tidak lepas dari meningkatnya penggunaan Internet. Internet merupakan media yang populer di kalangan remaja. Survei yang dilakukan oleh Asosiasi Penyelenggara Jaringan Internet Indonesia (APJII) mengungkap bahwa lebih dari setengah penduduk Indonesia kini telah terhubung ke internet. Survei yang dilakukan sepanjang 2016 itu menemukan bahwa 132,7 juta orang Indonesia telah terhubung internet. Adapun total penduduk Indonesia sendiri sebanyak 256,2 juta orang. Hal ini mengindikasikan kenaikan 51,8\% dibandingkan jumlah pengguna internet pada 2014. Survei yang dilakukan APJII pada 2014 hanya ada 88 juta pengguna internet. Data survei juga mengungkap bahwa 67,2 juta orang atau 50,7\% mengakses internet melalui perangkat genggam dan komputer, 63,1 juta orang atau 47,6\% mengakses dari smartphone, dan 2,2 juta orang atau 1,7\% hanya mengakses dari komputer (Widiartanto, 2016). Selain itu, Polda Metro Jaya mencatat setiap hari terdapat 25 laporan kasus penghinaan dan pencemaran nama baik atau perundungan melalui media sosial (Verdhani, 2016).

Berdasarkan penelitian terdahulu perundungan maya dipengaruhi oleh harga diri (selfesteem) (Brewer \& Kerslake, 2015; Perren, Doley, Shaw \& Gross (Brack \& Caltabiano, 2014); Brighi, Melotti, Guarini, Genta, Ortega, Mora-Merchán, Smith, \& Thompson, 2012; Kowalski, Limber, \& Agatson, 2008; Patchin \& Hinduja, 2010), kesepian (loneliness) (Brewer \& Kerslake, 2015; Sahin, 2012; Larra naga, Yubero, Ovejero \& Navarro, 2016), prestasi akademik ranah afektif (Beran \& Li, 2007; Tokunaga, 2010; Ma, 2001), jenis kelamin (Kowalski \& Limber, 2007; Price \& Dalgleish, 2010; Low \& Espelange, 2013; Li, 2005; Guarini, Melotti \& Brighi, 2012), dan tingkat kelas (Tokunaga, 2010; Chalvete, Orue, Estevaz, Villardon, \& Padilla, 2010; Ortega et. al., 2012).

Pada penelitian sebelumnya, beberapa peneliti (Kowalski \& Limber, 2007; Kowalski et al., 2008; Kowalski \& Limber, 2013; Ybarra \& Mitchel, 2004; Ybarra et al., 2007; Li, 2005) 
telah menguji karakteristik dari responden perundungan maya. Hasil penelitian mereka menemukan bahwa terdapat lingkaran pelaku-korban (bully-victim circle), artinya partisipan yang pernah berperan sebagai pelaku perundungan maya, pernah juga mengalami korban perundungan maya. Karakteristik kelompok responden perundungan maya yang mereka temukan terdiri dari pelaku saja, korban saja, pelaku-korban, dan yang tidak terlibat perundungan maya.

Dari data-data dan temuan penelitian di atas, penulis menyimpulkan bahwa perundungan maya adalah masalah sosial yang serius dan meluas serta cepat penyebarannya. Untuk itu perlu dilakukan tindakan preventif untuk mengurangi dampak negatif perundungan maya yang ditimbulkan seperti: depresi, cemas, atau harga diri rendah. Penulis berasumsi bahwa variabel harga diri, kesepian pada teman, kesepian pada orang tua, kesepian (bersikap negatif), kesepian (bersikap positif), prestasi akademik ranah afektif dan variabel demografi (jenis kelamin dan tingkat kelas) merupakan prediktor yang mempengaruhi pelaku dan korban perundungan maya.

\section{Harga diri dan perundungan maya}

Harga diri merupakan suatu sikap evaluasi positif ataupun negatif terhadap diri sendiri (self). Dengan kata lain harga diri adalah bagaimana seseorang memandang dirinya sendiri. Anak dengan harga diri yang tinggi tidak akan melakukan perundungan maya, begitu juga sebaliknya anak dengan harga diri rendah cenderung akan melakukan perundungan maya, baik dia sebagai pelaku ataupun korban (Kowalski \& Limber, 2008). Hal ini berarti bahwa harga diri memiliki peran yang penting dalam pembentukan karakter anak. Peningkatan harga diri yang tinggi pada siswa perlu dikembangakan agar perilaku mereka mengarah pada halhal yang positif bukan pada hal yang negatif, seperti perilaku perundungan maya.

\section{Kesepian dan perundungan maya}

Kesepian dalam penelitian ini memiliki empat dimensi: 1) Kesepian pada teman, yaitu perasaan penolakan, pengabaian, dan desersi terjadi dalam hubungannya dengan teman sebaya. 2) Kesepian pada orang tua yang dimaksud dalam penelitian ini adalah perasaan penolakan, ditinggalkan, dan desersi terjadi dalam hubungan dengan orang tua. 3) Kesepian (negatif) yang dimaksud dalam penelitian ini adalah sikap negatif terhadap kesepian. 4) Kesepian (positif) yang dimaksud dalam penelitian ini adalah sikap positif terhadap kesepian. Kesepian memiliki korelasi yang positif bagi korban perundungan maya (Sahin, 2012). Berdasarkan hasil penelitian Hunt, Peters, dan Rapee (2012) korban perundungan maya memiliki kecerdasan sosial yang negatif. Selanjutnya, Guarini et al (2012) tidak menemukan adanya kesepian pada pelaku perundungan maya. Artinya, siswa remaja yang cenderung menjadi korban perundungan maya adalah mereka yang menyendiri karena merasa kesepian serta siswa yang kurang mampu mengembangkan keterampilan sosial akan mudah diganggu (menjadi korban). 


\section{Prestasi akademik ranah afektif dan perundungan maya}

Pelaku atau korban perundungan maya memiliki kinerja akademik lebih rendah dibandingkan dengan mereka yang tidak terlibat perundungan maya (Kowalski \& Limber, 2013; Kowalski, Limber, \& Agatston, 2012). Beran dan Li (2007); Tokunaga (2010) dalam penelitiannya menemukan bahwa siswa yang memiliki prestasi rendah akan melakukan perundungan baik di sekolah, di ruang dunia maya, atau di keduanya. Penelitian serupa dilakukan oleh Ma (2001) yang menemukan bahwa siswa yang lemah dalam hal ranah afektif akan lebih mudah menjadi pengganggu atau korban di dunia maya. Hal itu menunjukkan bahwa siswa yang melakukan perilaku perundungan di dunia maya cenderung mengabaikan sikap-sikap yang terpuji sesuai dengan norma sosial.

\section{Jenis kelamin dan perundungan maya}

Perempuan lebih banyak menjadi pelaku dan juga korban perundungan maya daripada perundungan tradisional (fisik), seperti mengintimidasi di dunia maya (menyebarkan rumor/ gosip, memberikan komentar yang merendahkan). Sedangkan pada pelaku perundungan maya lebih banyak ditemukan pada jenis kelamin laki-laki (Li, 2005; Ma, 2001; Aricak, 2009; Huang \& Chow, 2010). Hal itu mengandung arti bahwa jenis kelamin khususnya perempuan sangat memungkinkan terlibat dalam perundungan maya.

\section{Tingkat kelas dan perundungan maya}

Masa remaja merupakan masa dengan emosi yang labil sehingga para remaja mudah dipengaruhi oleh teman sebaya dan lingkungannya. Perundungan maya dimulai ketika siswa berada di tingkat sekolah dasar, sekolah menengah pertama, sekolah menengah lanjutan, dan perguruan tinggi. Namun puncak dari perilaku perundungan maya akan terlihat jelas ketika pada anak usia 13-17 tahun (SMP-SMA). Seiring usia bertambah, maka tingkat perundungan maya akan cenderung menurun dibandingkan sebelumnya.

Berdasarkan penjelasan diatas, maka tujuan dari penelitian ini adalah menguji variabel prediktor yang mempengaruhi pelaku dan korban perundungan maya. Hipotesis utama yang diajukan oleh peneliti adalah: 1) Terdapat pengaruh harga diri, kesepian pada teman, kesepian pada orang tua, kesepian bersifat negatif, kesepian bersifat positif, prestasi akademik ranah afektif, dan variabel demografis terhadap pelaku perundungan maya pada remaja SMP wilayah Tangerang Selatan. 2) Terdapat pengaruh bersama yang signifikan prediktor: harga diri, kesepian pada teman, kesepian pada orang tua, kesepian bersifat negatif, kesepian bersifat positif, prestasi akademik ranah afektif, dan variabel demografis terhadap korban perundungan maya pada remaja SMP wilayah Tangerang Selatan.

\section{METODE}

Penelitian ini melibatkan dua jenis variabel, yakni variabel independen dan variabel dependen. Variabel terikat dalam penelitian ini adalah perundungan maya. Sedangkan 
variabel bebas dalam penelitian ini adalah, harga diri, kesepian pada teman, kesepian pada orang tua, kesepian bersifat negatif, kesepian bersifat positif, dan prestasi akademik ranah afektif. Skala yang digunakan dalam penelitian ini yaitu: skala perundungan maya untuk pelaku (Skala Pelaku CB) dan perundungan maya untuk korban (skala Korban CB). Skala Harga Diri (RSES), Skala Kesepian pada teman (skala LLCA), Skala Kesepian pada orang tua (skala LLCA), Kesepian negatif (skala LLCA), kesepian positif (skala LLCA), dan skala prestasi akademik ranah afektif. Variabel terikat penelitian ini mengukur ketujuh bentuk dari perundungan maya, yaitu: flaming, harassment, denigration, impersonation, outing dan trickery, exclusion, cyberstalking.

\section{Partisipan}

Populasi penelitian ini adalah semua pelajar siswa siswi di SMP wilayah Tangerang Selatan kelas VII, VIII. Dalam penelitian ini sampel yang yang digunakan sebanyak 313 siswa, terdiri dari 166 siswa laki-laki dan 147 siswa perempuan. Penelitian ini menggunakan jenis penelitian probabililty sampling dengan teknik simple random sampling.

\section{Instrumen}

Dalam pengujian validitas instrumen digunakan CFA (Confirmatory Factor Analysis) sehingga dapat diketahui apakah seluruh item mengukur apa yang hendak diukur dan apakah masing-masing item signifikan dalam mengukur hal tersebut. Adapun logikanya adalah dengan cara membandingkan sejauh mana matriks korelasi hasil estimasi menggunakan teori dengan matriks korelasi yang diperoleh dari data. Dalam hal ini, teori adalah konsep bahwa seluruh item mengukur satu hal yang sama (unidimensional) yaitu konstruk yang hendak diukur. Hasilnya, seluruh instrumen menghasilkan model yang fit (Tabel 1).

Tabel 1

Validitas Instrumen berdasarkan CFA

\begin{tabular}{lrrrr}
\hline Instrumen & Jumlah item & Chi Square & p-value & RMSEA \\
\hline Pelaku perundungan maya & 10 & 35,63 & 0,000 & 0,032 \\
Korban perundungan maya & 15 & 88,26 & 0,693 & 0,029 \\
Harga Diri & 10 & 39,95 & 0,052 & 0,039 \\
Kesepian dengan Teman & 12 & 54,32 & 0,096 & 0,031 \\
Kesepian dengan Orang Tua & 12 & 55,95 & 0,089 & 0,031 \\
Kesepian Negatif & 12 & 46,75 & 0,089 & 0,033 \\
Kesepian Positif & 12 & 51,94 & 0,165 & 0,026 \\
Prestasi Afektif Akademik & 25 & 208,01 & 0,613 & 0,023 \\
\hline
\end{tabular}

\section{HASIL}

Peneliti menguji hipotesis dengan teknik analisis regresi ganda. Dalam melakukan analisis regresi ada tiga hal yang perlu diperhatikan, yaitu melihat besaran $R$ square untuk mengetahui sumbangan (persentase) keseluruhan independen variabel terhadap keseluruhan 
kelompok-kelompok variabel dependen, melihat apakah variabel independen berpengaruh secara signifikan terhadap variabel dependen, dan melihat signifikan atau tidaknya regresi dari independen variabel terhadap masing-masing kelompok variabel dependen.

Berdasarkan tabel 2 dapat dilihat bahwa perolehan $\mathrm{R}$ square sebesar 0.175 atau $17.5 \%$. Hal tersebut berarti proporsi varian dari pelaku perundungan maya yang dijelaskan oleh variabel independen: harga diri, kesepian pada teman, kesepian pada orang tua, kesepian bersifat negatif, kesepian bersifat positif, prestasi akademik, jenis kelamin dan kelas adalah sebesar $17.5 \%$, sedangkan sisanya $82.5 \%$ disebabkan oleh variabel lain di luar penelitian ini.

Tabel 2

Ringkasan Model

\begin{tabular}{|c|c|c|c|c|c|c|}
\hline \multirow[b]{2}{*}{$\mathrm{R}$} & \multirow[b]{2}{*}{ R Square } & \multicolumn{5}{|c|}{ Change Statistics } \\
\hline & & $\begin{array}{l}\text { R Square } \\
\text { Change }\end{array}$ & F Change & df1 & $\mathrm{df} 2$ & $\begin{array}{c}\text { Sig. F } \\
\text { Change }\end{array}$ \\
\hline $.419^{a}$ & .175 & .175 & 8.020 & 8 & 302 & .000 \\
\hline
\end{tabular}

Tabel 3

Anova Regresi Prediktor terhadap Pelaku Perundungan Maya

\begin{tabular}{llrrrrr}
\hline \multicolumn{1}{c}{ Model } & \multicolumn{2}{c}{ Sum of } & & & & \\
\hline 1 & Squares & df & Mean Square & \multicolumn{1}{c}{ F } & \multicolumn{1}{c}{ Sig. } \\
& Regression & 4122.696 & 8 & 515.337 & 8.020 & $.000^{\text {a }}$ \\
& Residual & 19405.497 & 302 & 64.257 & & \\
& Total & 23528.192 & 310 & & & \\
\hline
\end{tabular}

a. Predictors: (Constant), kelas, jenis kelamin, kesepian_teman, kesepian_ortu, kesepian_neg, kesepian_pos, harga diri, prestasi akademik afektif

b. Variabel dependen: pelaku perundungan maya

Tabel 4

Koefisien Regresi Prediktor terhadap Pelaku Perundungan Maya

\begin{tabular}{|c|c|c|c|c|c|c|}
\hline & & \multicolumn{2}{|c|}{$\begin{array}{l}\text { Unstandardized } \\
\text { Coefficients }\end{array}$} & \multirow{2}{*}{$\begin{array}{c}\text { Standardized } \\
\text { Coefficients } \\
\text { Beta }\end{array}$} & \multirow[b]{2}{*}{$\mathrm{T}$} & \multirow[b]{2}{*}{ Sig. } \\
\hline \multicolumn{2}{|c|}{ Model } & B & Std. Error & & & \\
\hline 1 & (Constant) & 52.575 & 3.414 & & 15.398 & .000 \\
\hline & Harga diri & .749 & .980 & .043 & .765 & .445 \\
\hline & Kesepian_teman & 4.071 & .970 & .234 & 4.199 & $.000^{*}$ \\
\hline & Kesepian_ortu & -.083 & 1.019 & -.005 & -.082 & .935 \\
\hline & Kesepian_neg & -.134 & .952 & -.008 & -.141 & .888 \\
\hline & Kesepian_pos & -.529 & .968 & -.030 & -.546 & .585 \\
\hline & Prestasi & -5.026 & 1.017 & -.288 & -4.943 & $.000^{*}$ \\
\hline & Jenis kelamin & -2.210 & .955 & -.127 & -2.315 & $.021^{*}$ \\
\hline & Kelas & .734 & .932 & .042 & .788 & .432 \\
\hline
\end{tabular}


Tabel 3 menunjukkan nilai sig. varian regresi adalah $0.000(<0,05)$ yang artinya bahwa model regresi signifikan. Maknanya adalah minimal salah satu variabel independen secara parsial berpengaruh terhadap variabel dependen. Dalam tabel 4 terlihat bahwa tiga prediktor yang signifikan yaitu kesepian terhadap teman, prestasi akademik ranah afektif, dan jenis kelamin terhadap pelaku perundungan maya. Proporsi varian (kontribusi) masing-masing prediktor terhadap pelaku perundungan maya (tabel 5), menunjukkan bahwa proporsi varian atau kontribusi terbesar ( $\mathrm{R}$ square change) prediktor yang signifikan adalah prediktor kesepian teman $(0,074)$, prestasi $(0,074)$, dan jenis kelamin $(0,015)$. Lima prediktor memiliki kontribusi sangat kecil sehingga tidak signifikan konribusinya.

Tabel 5

Proporsi varian masing-masing pelaku perundungan maya

\begin{tabular}{|c|c|c|c|c|c|c|c|}
\hline \multirow[b]{2}{*}{ Model } & \multirow[b]{2}{*}{$\mathrm{R}$} & \multirow{2}{*}{$\begin{array}{c}\mathrm{R} \\
\text { Square }\end{array}$} & \multicolumn{5}{|c|}{ Change Statistics } \\
\hline & & & $\begin{array}{l}\text { R Square } \\
\text { Change }\end{array}$ & F Change & df1 & df2 & $\begin{array}{c}\text { Sig. F } \\
\text { Change }\end{array}$ \\
\hline 1 & $.034^{\mathrm{a}}$ & .001 & .001 & .350 & 1 & 309 & .555 \\
\hline 2 & $.274^{\mathrm{b}}$ & .075 & .074 & 24.594 & 1 & 308 & .000 \\
\hline 3 & $.287^{c}$ & .082 & .007 & 2.453 & 1 & 307 & .118 \\
\hline 4 & $.288^{\mathrm{d}}$ & .083 & .001. & .240 & 1 & 306 & .624 \\
\hline 5 & $.290^{\mathrm{e}}$ & .084 & .001 & .255 & 1 & 305 & .614 \\
\hline 6 & $.398^{\mathrm{f}}$ & .159 & .075 & 27.063 & 1 & 304 & .000 \\
\hline 7 & $.417 \mathrm{~g}$ & .174 & .015 & 5.435 & 1 & 303 & .020 \\
\hline 8 & $.419^{\mathrm{h}}$ & .175 & .002 & .620 & 1 & 302 & .432 \\
\hline
\end{tabular}

Tabel 6

R Square Prediktor terhadap Korban Perundungan maya

\begin{tabular}{|c|c|c|c|c|c|c|c|}
\hline \multirow[b]{2}{*}{ Model } & \multirow[b]{2}{*}{$\mathrm{R}$} & \multirow[b]{2}{*}{$\begin{array}{c}\mathrm{R} \\
\text { Square }\end{array}$} & \multicolumn{5}{|c|}{ Change Statistics } \\
\hline & & & $\begin{array}{l}\text { R Square } \\
\text { Change }\end{array}$ & $\begin{array}{c}\text { F } \\
\text { Change }\end{array}$ & df1 & df2 & Sig. F Change \\
\hline 1 & $.315^{\mathrm{a}}$ & .099 & .099 & 4.169 & 8 & 302 & .000 \\
\hline
\end{tabular}

Berdasarkan tabel 6 dapat dilihat bahwa perolehan R square sebesar 0.099 atau 9.9\%. Hal tersebut berarti proporsi varian dari korban perundungan maya yang dijelaskan oleh variabel independen: harga diri, kesepian pada teman, kesepian pada orang tua, kesepian bersifat negatif, kesepian bersifat positif, prestasi akademik, jenis kelamin dan kelas adalah sebesar 9.9\%. Sedangkan sisanya $90.1 \%$ disebabkan oleh variabel lain di luar penelitian ini. 
Tabel 7

Anova Korban Perundungan Maya

\begin{tabular}{llrrrrr}
\hline \multicolumn{2}{l}{} & \multicolumn{1}{c}{ Sum of } & \multicolumn{3}{c}{ Mean } \\
\multicolumn{1}{l}{ Model } & Squares & df & Square & \multicolumn{1}{c}{ F } & \multicolumn{1}{c}{ Sig. } \\
\hline 1 & Regression & 2453.050 & 8 & 306.631 & 4.169 & $.000^{\text {a }}$ \\
& Residual & 2212.407 & 302 & 73.551 & & \\
& Total & 24665.458 & 310 & & & \\
\hline
\end{tabular}

a. Predictors: (Constant), kelas, jenis kelamin, kesepian_teman, kesepian_ortu, kesepian_neg, kesepian_pos, harga diri, prestasi akademik afektif.

b. Variabel dependen: korban Cyberbullying.

Tabel 8

Koefisien Regresi Korban Perundungan Maya

\begin{tabular}{|c|c|c|c|c|c|c|}
\hline & & \multicolumn{2}{|c|}{$\begin{array}{c}\text { Unstandardized } \\
\text { Coefficients }\end{array}$} & \multirow{2}{*}{$\begin{array}{c}\text { Standardized } \\
\text { Coefficients } \\
\text { Beta } \\
\end{array}$} & \multirow[b]{2}{*}{$\mathrm{t}$} & \multirow[b]{2}{*}{ Sig. } \\
\hline \multicolumn{2}{|c|}{ Model } & B & Std. Error & & & \\
\hline 1 & (Constant) & 47.146 & 3.653 & & 12.906 & .000 \\
\hline & Harga diri & -.798 & 1.048 & -.045 & -.761 & .447 \\
\hline & Kesepian_teman & 3.216 & 1.037 & .180 & 3.100 & $.002 *$ \\
\hline & Kesepian_ortu & -.017 & 1.091 & -.001 & -.016 & .987 \\
\hline & Kesepian_neg & 1.431 & 1.018 & .080 & 1.406 & .161 \\
\hline & Kesepian_pos & .929 & 1.035 & .052 & .897 & .370 \\
\hline & Prestasi & -2.918 & 1.088 & -.163 & -2.682 & $.008 *$ \\
\hline & Jenis kelamin & .831 & 1.021 & .047 & .814 & .416 \\
\hline & Kelas & -.441 & .998 & -.025 & -.442 & .659 \\
\hline
\end{tabular}

Tabel 9

Proporsi varian variabel korban perundungan maya

\begin{tabular}{llrrrrrr}
\hline & \multicolumn{7}{c}{ Change Statistics } \\
Model & $\mathrm{R}$ & $\begin{array}{c}\mathrm{R} \\
\text { Square }\end{array}$ & $\begin{array}{c}\text { R Square } \\
\text { Change }\end{array}$ & \multicolumn{1}{c}{$\mathrm{F}$ Change } & df1 & \multicolumn{1}{c}{ df2 } & Sig. F Change \\
\hline 1 & $.108^{\mathrm{a}}$ & .012 & .012 & 3.648 & 1 & 309 & .057 \\
2 & $.247^{\mathrm{b}}$ & .061 & .049 & 16.159 & 1 & 308 & .000 \\
3 & $.251^{\mathrm{c}}$ & .063 & .002 & .721 & 1 & 307 & .396 \\
4 & $.270^{\mathrm{d}}$ & .073 & .010 & 3.182 & 1 & 306 & .075 \\
5 & $.277^{\mathrm{e}}$ & .077 & .004 & 1.294 & 1 & 305 & .256 \\
6 & $.311^{\mathrm{f}}$ & .097 & .020 & 6.786 & 1 & 304 & .010 \\
7 & $.314^{\mathrm{g}}$ & .099 & .002 & .678 & 1 & 303 & .411 \\
8 & $.315^{\mathrm{h}}$ & .099 & .001 & .195 & 1 & 302 & .659 \\
\hline
\end{tabular}

Dari tabel 7 dapat diketahui bahwa nilai sig. (signifikan) analisis varian regresi adalah $0.000(<0,05)$ atau signifikan. Hasil signifikan ini bisa diartikan bahwa ada 
variabel prediktor yang mampu memprediksi korban perundungan maya yaitu kesepian teman dan prestasi (tabel 8). Dua prediktor tersebut masing-masing berpengaruh negatif (kesepian teman) dan negatif (prestasi). Sebagai prediktor yang signifikan maka dua prediktor, kesepian teman dan prestasi memiliki kontribusi yang paling besar yaitu 0,049 dan 0,020. Prediktor-prediktor lain memiliki kontribusi yang sangat kecil sehingga tidak signifikan dalam meregresi korban perundungan maya.

\section{PEMBAHASAN}

Penelitian ini menunjukkan variabel apa saja yang bisa memprediksi perundungan maya pada remaja baik dari sisi korban maupun pelaku. Hasil penelitian ini menemukan bahwa responden memiliki variasi dalam keterlibatan perundungan maya, bisa saja hanya terlibat sebagai korban atau pelaku saja tapi juga bisa sebagai pelaku sekaligus korban. Penelitian sebelumnya (Kowalski \& Limber, 2007; Kowalski et al., 2008; Kowalski \& Limber, 2007; Ybarra \& Mitchel, 2004; Ybarra et al., 2007; Li, 2005) menemukan bahwa terdapat lingkaran pelaku-korban (bully-victim circle), yaitu pelaku perundungan maya pernah mengalami korban perundungan maya. Karakteristik kelompok responden perundungan maya yang mereka temukan terdiri dari pelaku saja, korban saja, pelaku-korban, dan yang tidak terlibat perundungan maya.

Penelitian ini juga menemukan bahwa perangkat elektronik yang sering digunakan untuk mengakses internet adalah smartphone (89\%), laptop (4\%), dan tablet/tab (3\%). Media yang banyak digunakan adalah line (25\%), BBM (24\%), Instagram (24\%), facebook (10\%), dan What's App (WA) (9\%). Hal ini menunjukkan bahwa aplikasi line lebih disukai oleh pelaku untuk melakukan perundungan maya dibandingkan aplikasi lainnya. Sementara, korban perundungan maya banyak diintimidasi melalui media BBM $(30 \%)$, line (26\%), instagram (20\%), facebook (11\%), dan What's App (WA) (6\%). Hal ini menunjukkan bahwa aplikasi BBM lebih sering diterima korban dalam peristiwa perundungan maya dibandingkan aplikasi lainnya.

Bentuk perundungan maya yang banyak dilakukan oleh pelaku perundungan maya (cyber-bullies) dalam penelitian ini adalah harassment (29\%), exclusion (24\%), impersonation (23\%), cyber-stalking (14\%), flaming (5\%), denigration (4\%), outing (4\%) dan trickery (4\%). Hal ini menunjukkan bahwa bentuk perundungan maya pada pelaku yang tertinggi yaitu harassment, yaitu mengirimkan pesan berupa kata-kata menghina.

Bentuk perundungan maya yang banyak dialami korban (cyber-victim) adalah impersonation $31 \%$, exclusion (27\%), cyber-stalking (16\%), harassment (8\%) dan denigration (8\%), flaming (5\%) dan outing \& trickery (5\%). Hal ini menunjukkan bahwa bentuk perundungan maya pada korban yang tertinggi yaitu impersonation, yaitu menjadi korban dari pembajakan orang lain agar korban terlibat masalah atau bahaya untuk merusak reputasi. 
Rata-rata responden melakukan aktivitas online dalam sepekan selama kurang dari 5 jam dengan jumlah responden sebanyak 107 (34.2\%, $\mathrm{M}=2.21, \mathrm{SD}=1.12)$. Pada penelitian ini terdapat pelaku dan koban perundungan maya yang rendah. Remaja yang meluangkan waktu lebih banyak untuk online maka akan menyebabkan peningkatan pada keterlibatan perundungan maya baik sebagai pelaku atau korban, sebaliknya remaja yang meluangkan waktu lebih sedikit untuk online maka kecenderungan terlibat dalam perundungan maya lebih rendah.

Penelitian ini dilakukan sebagai usaha untuk mengetahui adanya pengaruh prediktor variabel harga diri, kesepian pada teman, kesepian pada orang tua, kesepian bersifat negatif, kesepian bersifat positif, prestasi akademik ranah afektif, dan variabel demografi terhadap pelaku perundungan maya, korban perundungan maya. Penelitian ini menghasilkan variabel kesepian pada teman, prestasi akademik ranah afektif, dan jenis kelamin dapat mempengaruhi pelaku perundungan maya. Hasil penelitian variabel kesepian pada teman ini berbeda dengan hasil penelitian yang telah dilakukan oleh Guarini et al (2012) yang tidak menemukan adanya pengaruh kesepian pada teman terhadap pelaku perundungan maya, tetapi menguatkan hasil penelitian Sahin (2012) dan Brewer dan Kerslake (2015) yang menemukan pengaruh yang signifikan kesepian terhadap pelaku perundungan maya. Selanjutnya, variabel prestasi akademik ranah afektif yang rendah turut mempengaruhi pelaku perundungan maya. Hasil penelitian ini mendukung penelitian sebelumnya yang dilakukan oleh Ma (2001) bahwa siswa yang lemah dalam hal ranah afektif akan lebih mudah menjadi pengganggu di dunia maya.

Faktor jenis kelamin turut mempengaruhi pelaku perundungan maya. Hasil penelitian ini menunjukkan bahwa mean pada kelompok laki-laki lebih tinggi dari perempuan. Hasil ini sejalan dengan Li (2005), bahwa lebih dari 52\% pelaku perundungan maya adalah kelompok laki-laki. Demikian juga hasil penelitian Huang dan Chow (2010), Ma (2001) dan Aricak (2009) yang mengatakan bahwa jenis kelamin laki-laki memiliki skor lebih tinggi pada pelaku dan korban. Begitu juga penelitian Guarini dkk. (2012), mengatakan pelaku perundungan maya lebih diwakili oleh kelompok laki-laki pada jenis perundungan tradisional maupun perundungan maya.

Kemudian dalam penelitian ini juga didapat bahwa variabel kesepian pada teman dan prestasi akademik ranah afektif yang dapat mempengaruhi korban perundungan maya. Variabel kesepian pada teman secara positif memiliki pengaruh signifikan terhadap korban perundungan maya, semakin tinggi kesepian pada teman maka akan semakin tinggi menjadi korban perundungan maya. Penelitian sebelumnya menyebutkan bahwa korban perundungan maya dihubungkan dengan tingginya perasaan kesepian, baik kesepian pada teman maupun kesepian pada orang tua (Brighi dkk., 2012). Hasil penelitian ini juga mendukung penelitian Hunt, Peter, dan Rapee (2012) bahwa korban perundungan maya memiliki kecerdasan sosial yang negatif. Dalam hal ini diasumsikan bahwa kurangnya keterampilan sosial sebagai akibat dari kurangnya inter- 
aksi sosial dengan lingkungan, hal ini juga bisa dikatakan sebagai orang yang merasa kesepian. Hasil penelitian yang serupa menemukan bahwa siswa yang menjadi korban perundungan maya adalah yang mengalami kesepian (Brewer \& Kerslake, 2015.) Selanjutnya, Sahin (2012), Larra Naga dkk., (2016) menemukan bahwa ada hubungan yang signifikan antara korban perundungan maya dengan kesepian.

Selanjutnya, variabel prestasi akademik ranah afektif secara negatif memiliki pengaruh yang signifikan terhadap korban perundungan maya, semakin rendah prestasi akademik ranah afektif maka akan semakin tinggi menjadi korban perundungan maya. Penelitian ini mendukung penelitian Ma (2001) bahwa siswa yang lemah dalam hal ranah afektif akan lebih mudah menjadi korban di dunia maya.

\section{KESIMPULAN}

Prediktor kesepian pada teman, prestasi akademik, dan jenis kelamin, mampu memprediksi pelaku perundungan maya. Selanjutnya, terdapat pengaruh prediktor kesepian pada teman dan prestasi akademik ranah afektif, terhadap korban perundungan maya. Saran-saran terkait dengan hasil penelitian ini patut dipertimbangkan untuk penelitian selanjutnya. Diharapkan pada penelitian selanjutnya adanya data kontrol untuk melihat frekuensi pengalaman keterlibatan dalam perundungan maya baik sebagai pelaku atau korban. Selanjutnya dalam menyusun alat instrumen sebaiknya melalui prosedur yang sesuai seperti adanya penerjemah dan penerjemah kembali agar tidak terjadi kekeliruan pada siswa dalam memahami item.

\section{DAFTAR PUSTAKA}

Aricak, O.T. (2009). Psychiatric symptomatology as a predictor of cyberbullying among university students. Egitim Arastirmalari-Eurasian Journal of Educational Research, 34, 167-184.

Brack, K., \& Caltabiano, N. (2014). Cyberbullying and self-esteem in Australian adults. Cyberpsychology: Journal of psychosocial research on mayaspace, 8(2), article 7. doi: 10.5817/CP2014-2-7

Beran, T., \& Li, Q. (2007). The relationship between Cyberbullying and school perundungan. Journal of student wellbeing. Vol. 1(2), 15-33.

Brewer, G., \& Kerslake, J. (2015). Cyberbullying, self-esteem, empathy and loneliness. Journal of computers in human behavior 48 255-260. doi.org/10.1016/j.chb. 2015.01. 073

Brighi, A., Melotti, G., Guarini, A., Genta, M.L., Ortega, R., Mora-Merchán J., Smith P.K., \& Thompson F. Dalam Qing Li, Donna Cross, \& Peter K. Smith (Eds). (2012). 
Cyberbullying in the global playground: Research from international perspectives, First Edition. Self-esteem and loneliness in relation to Cyberbullying in three European countries. Blackwell Publishing Ltd.

Goebert, D., Else, I., Matsu, C., Chung-do, J., \& Chang, J.Y. (2011). The impact of Cyberbullying on substance use and mental Health in a multiethnic sample. Matern child health journal. 15:1282-1286. Doi 10.1007/s10995-010-0672-x

Guarini A., Passini S., Melotti G., \& Brighi A. (2012). Risk and protective factors on perpetration of perundungan and Cyberbullying. Studia Edukacyjne nr 23, 2012, Poznań 2012, pp. 33-55. Adam Mickiewicz University Press. ISBN 978-83-2322520-1. ISSN 1233-6688

Huang, Y., \& Chou, C. (2010). An analysis of multiple factors of Cyberbullying among junior high schoool students in Taiwan. Journal of computers in human behavior, 26 (2010) 1581-1590. doi: 10.1016/j.chb.2010.06.005

Kowalski R. M., \& Limber S.P. (2007). Electronic perundungan among middle school students. Journal of Adolescent Health. doi: 10.1016/j.jadohealth. 2007.08.017.

Kowalski, R.M., Limber, S.P., \& Agatson, P.W. (2008). Cyber-bullying: Bullying in digital age. Victoria: Blackwell Publishing

Kowalski R. M., \& Limber, S.P. (2013). Psychological, physical, and academic correlates of Cyberbullying and traditional bullying. Journal of adolescenct health. http://dx.doi.org./ 10.1016/j.jadohealth.2012.09.018

Kowalski, R.M., Giumetti, G.W., Schroeder, A.N., \& Lattanner, M.R. (2014). Perundungan in the digital age: A critical review and meta-analysis of Cyberbullying research among youth. Psychological Bulletin. Vol. 140, No. 4, 10731137. DOI: $10.1037 / \mathrm{a} 0035618$

Lai, S. Ye, R. \& Chang, K. (2008). Bullying in Middle Schools: An Asian-Pacific Regional Study. Asia Pacific Education Review. Vol. 9, No.4, 503-515.

Larra naga, E., Yubero, S., Ovejero, A., \& Navarro, R. (2016). Loneliness, parentchild communication and Cyberbullying victimization among Spanish youths. Computers in Human Behavior. 65 1e8. doi.org/10.1016/j.chb.2016.08.015.

Low, S., \& Espelange, D. (2013). Differentiating cyber-bullying perpetration from nonphysical bullying: commonalities across race, individual, and family predictors. Journal of psychology of violance. Vol.3, No. 1, 39-52. doi: 10.1037/a0030308

Ma, X. (2001). Bullying and being bullied: To what extent are bullies also victims?. American Educational Research Journal, Vol. 38, No. 2 (Summer, 2001), pp. 351370. 
Ortega R., Elipe P., Mora-Merchán J.A, Genta M.L., Brighi A., Guarini A, Smith P.K., Thompson F., \& Tippet N. (2012). The emotional impact of perundungan and Cyberbullying on victims: A European cross-national study. Aggressive behavior. Volume 38, pages 342-356. doi: 10.1002/ ab.21440

Olweus, D. (2012). Invited expert discussion paper Cyberbullying: an overrated phenomenon? European journal of developmental psychology. 1-19, ifirst article.

Patchin, J.W., \& Hinduja, S. (2006). Bullies move beyond the schoolyard a preliminary look at Cyberbullying. Youth violence and juvenile justice, Vol. 4 No. 2, 148-169. DOI: $10.1177 / 1541204006286288$.

Patchin, J.W., \& Hinduja, S. (2010). Cyberbullying and self-esteem. Journal of school health, 80, 614-621. http://dx.doi.org/10.1111/j.1746-1561.2010.00548.x

Patchin J.W. \& Hinduja S. (2013). Social influences on Cyberbullying behaviors among middle and high school students. Journal of youth and adolescence. doi: 10.1007/s10964-012-9902-4

Price, M \& Dalgleish, J. (2010). Cyberbullying experiences, impacts and coping strategies as described by Australian young people. Youth studies Australia volume 29 number 2 .

Rosenberg, M., Schooler, C., Schoenbach, C., \& Rosenberg, F. (1995). Global selfesteem and specific self-esteem: different concepts, different outcomes. Journal of American Sociological Review, Vol. 60, No. 1 (Feb., 1995), pp. 141-156

Şahin M. (2012). The relationship between the Cyberbullying/mayavictmization and loneliness among adolescents. Journal of children and youth services review 34 (2012) 834-837. doi:10.1016/j.childyouth.2012.01.010

Shariff, S. (2008). Cyber-bullying: Issues and solutions for the school, the classroom and the home. New York: Routledge

Shariff, S. (2009). Confronting cyber-bullying. What school need to know to control misconduct and avoid legal consequences. New York: Cambridge University Press

Tokunaga R. S. (2010). Following you home from school: A critical review and synthesis of research on Cyberbullying victimization. Journal of Computer in Human Behavior. doi:10.1016/j.chb.2009.11.014

Verdhani, M.H. (2016). Setiap Hari Polda Terima Laporan 25 Perundungan maya. Diunduh dari https://metro.sindo-news.com/read/1128434/170/setiap-hari-poldaterima-laporan-25-maya-perundungan-1470211776

Willard, N. (2007). Educator's guide to Cyberbullying addressing the harm caused by online social cruelty. Diunduh dari http://mayabully.org or http://csriu.org 
Willard, N. (2007). Cyberbullying and cyberthreats: Responding to the Challenge of Online Social Aggression, Threats, and Distress. IL: Research Press (800-519-2707; www.research-press.com. Diunduh http://www.em-bracecivility.org/wp-content/up loadsnew/2012/10/appE.pdf

Widiartanto, Y.H. (2016). 2016, Pengguna internet di Indonesia capai 132 Juta. Diunduh dari http://tekno.kompas.com/read/2016/10/24/15064727/2016.pengguna. internet. di.indonesia.capai.132.juta.

Ybarra, M. L., Mitchell, K.J. (2004). Online aggressor/targets, aggressors, and targets: a comparison of associated youth characteristics. Journal of Child Psychology and Psychiatry 45:7, pp 1308-1316. doi:10.1111/j.1469-7610. 2004.00328.x

Ybarra, M. L., Espelage, D.L, Mitchell, K.J. (2007). The co-occurrence of internet harassment and unwanted sexual solicitation victimization and perpetration: Associations with psychosocial indicators. Journal of Adolescent Health 41 S31S41. doi:10.1016/ j.jadohealth.2007.09.010. 